\title{
Berlinale 2006
}

\author{
By Ron Holloway \\ Spring 2006 Issue of KINEMA
}

\section{$56^{\text {th }}$ BERLINALE 2006}

With 160,000 tickets sold and an overall audience of circa 400,000, the $56^{\text {th }}$ Berlinale (9-19 February 2006), the fifth under the aegis of Dieter Kosslick, will go down as the biggest, if not the best, in its festival history. Add to this the super success of the European Film Market (EFM) in the spacious Martin-Gropius-Bau where 5,162 accredited participants representing 250 companies from 51 countries promoted over 650 films with 1100 screenings - and you have perhaps the largest turnout ever recorded at a film market. Of course, the rescheduling of the American Film Market (AFM) from spring to autumn had something to do with the big numbers at the EFM in Berlin. The only bumps in the festival road are still the unpredictable winter weather (not too uncomfortable this year, however) and the five-minute walk (with your winter coat on) from the Berlinale headquarters on Potsdamer Platz to the EFM in the Gropius-Bau when you happened to miss the shuttle bus.

Asked by the media as to the highlights of this year's Berlinale, Dieter Kosslick at first quipped: "We even had an entry from Bhutan, only the second film ever produced in this corner of the Himalayas!" He was referring to the Special Screening of Neten Chokling's Milarepa, a biopic about the poet-monk (1052-1135) who became one of Tibet's great spiritual leaders. On a serious note, he also confirmed that he felt no qualms inviting three films that dealt with the troubles in the Near East and the war in Iraq: Michael Winterbottom and Mat Whitecross's The Road to Guantanamo (UK) and Stephen Gaghan's Syriana (USA) in the Competition, and Roberto Benigni's La tigre e la neve (The Tiger and the Snow, Italy) programmed as a Special Screening. Did this trio alone make the Berlinale a political festival? Not really, for there were other films in the Official Program of greater political depth and with more sociopolitical relevance. Since we are presently living in a time of crisis, film festivals can be an apt sounding-board in the public arena to pose questions and probe for answers.

\section{From Afghanistan to Iraq}

Three years ago, British director Michael Winterbottom was awarded the Golden Bear at the 2003 Berlinale for In This World, a film about Afghan refugees trying to make their way illegally to London. This year, he is back with The Road to Guantanamo, a barbed docu-drama about prison conditions in Guantanamo that reflects the pitfalls of the invasion of Afghanistan, but only on the surface. Based on actual events, Winterbottom and Whitecross recount the arrest in Afghanistan and deportation to Guantanamo of three British citizens of Pakistani background, youths who happened to be in the wrong place at the wrong time when the invasion of Afghanistan took place. Why the trio left a wedding party in Pakistan for a touring visit to Afghanistan is never adequately explained. Instead, the focus is entirely on their two-year detention in Guantanamo, where their treatment by the guards is depicted as anything but pleasant. On the other hand, because they speak English, their avenues of defence and routes to release were lighter than those of others still detained in the Cuban fortress without much hope of a fair trial in the foreseeable future. Although The Road to Guantanamo does not give any answers, it does nonetheless pose important questions on the consequences of a "war" currently conducted by the Bush administration. Michael Winterbottom and Mat Whitecross were awarded the Silver Bear for Best Direction at the Berlinale.

Stephen Gaghan's Syriana (USA), a George Clooney CIA-thriller, is written and directed by the same talented screenwriter who penned Steven Soderbergh's Traffic (2000), an indictment of drug trafficking in the USA. Thrillers usually help the viewer to decide which side to take, but not so in this case, for the oil business is as corrupt from the inside out as the CIA is from the outside in. There's also no reason to take anything seriously in Roberto Benigni's The Tiger and the Snow, a comedy about a poet (Benigni himself) so madly in love with a poetess (Nicoletta Braschi, his wife) that he follows her all the way to Iraq amid the bombings - and, of course, falls into the hands of the Americans. This farce supposedly set in Iraq pales in importance when placed alongside the winner of the Amnesty International Award: Masoud Arif Salih and Hussein Hassan Ali's Ü nergiz biskivin (Narcissus Blossom), an Iraqi-French coproduction filmed in the 
Kurd section of Iraq on the border to Iran. Programmed in the Panorama, Narcissus Blossom chronicles the efforts of the Peshmerga forces in their struggles to found an autonomous Kurdistan.

\section{Bears for Debut Directors}

No film at the Berlinale deserved the Golden Bear more than Jasmila Zbani's Grbavica (Bosnia-HerzegovinaCroatia-Austria-Germany), a debut feature film by a 31-year-old writer-director-actress with but two prior short films to her name. Indeed, Grbavica is a searing film of social conscience, its thematic content alone making it by far the most politically relevant film seen at the Berlinale. Add to this the fact that Grbavica, a suburb of Sarajevo, is symbolic of the agony of Muslim women raped by perpetrators of ethnic cleansing in the Balkans during the four-year siege (1992-95) of Sarajevo by Serb nationalists. According to Jasmila Zbani at her press conference, and voiced again on the stage of the Berlinale Palast when she was handed the Golden Bear by jury president Charlotte Rampling, some 20,000 East-Bosnian women of Moslem belief - some 14 and 15 years of age - were repeatedly raped by paramilitary Serbs before they were exchanged as pregnant women for captured Serb soldiers. The shame of bearing an unwanted child after being raped by a Serb soldier is what lends Grbavica a gravity that begs description. Of equal importance to the appreciation of the film is the fact that the actress playing the afflicted Muslim mother of a 12-year-old daughter, who wants to know if her father had really died in the war, is the eminent Serb stage-and-screen actress Mirjana Karanovi, who during the siege stood tall in Belgrade against the ethnic cleansing policies fostered by Yugoslav President Slobodan Milošević. "Other criminals are still at large," said Jasmila Zbani at her press conference. "Radko Mladić and Radovan Karadžić are responsible for the deaths of 100,000 civilians, in addition to the expulsion of millions from their homes, and we cannot look forward into the future until they are brought to justice." Grbavica also won the Ecumenical Prize and the Peace Film Award at the Berlinale.

A pair of Bears, the Silver Bear-Grand Jury Prize and the Golden (Little) Bear for Best Feature Film, were handed to a surprised Danish debutante, Pernille Fischer Christensen, for her delightful comedy-of-manners En Soap (A Soap, Denmark-Sweden). This low-budget tale of love and pain pairs a sensitive woman who has left an arrogant husband and a transvestite who is waiting for her sex-exchange operation. As the story unfolds in neatly stacked comic sex-episodes, a fragile, then ardent relationship develops between two outsiders, Charlotte (Trina Dyrholm) and Veronica (David Dencik), the upstairs-downstairs neighbours in a high-rise. As Charlotte's partners pass through her bedroom on a swinging-door regularity, Veronica is forced to sell her talents to make ends meet when she doesn't get enough sewing jobs. If that sounds rather weird, then take a close look at the title: $A$ Soap is a real-life edition of the regular airing of the transvestite's favourite soap on television.

\section{German Film Splurge}

Thanks to the finesse and foresight of Dieter Kosslick, no less than 55 German entries - features, documentaries, shorts - could be seen in all sections at the festival. Indeed, never before have so many German films been programmed at the Berlinale, not to mention extra market screenings and archival classics booked for the Retrospective titled "Traumfrauer - Film Stars of the Fifties." Booked for the Competition were four entries: Hans-Christian Schmid's Requiem, Oskar Roehler's Elementarteilchen (The Elementary Particles), Matthias Glasner's Der freie Wille (The Free Will), and Valeska Griesbach debut feature Sehnsucht (Longing) - and the quartet produced a trio of acting awards. The Silver Bear for Best Actress was awarded to Sandra Hüller for her performance in Requiem as a young epileptic, a bright and eager student at Tübingen University, whose penchant for hearing voices is misinterpreted as possession by the devil. Based on an actual incident that occurred in an isolated Catholic community at the beginning of the 1970s, Requiem unfortunately rarely strays from the human drama at hand - an epileptic suffering as much under the hard hand of an unloving mother as her devotion to Mary and the Saints abetted by a strict religious upbringing. Since the "requiem" in the title refers indirectly to an exorcism that never actually takes place in the film, save for a few initial and unresolved encounters with a self-proclaimed "Man of God," what conclusions, if any, are to be drawn from Schmid's directorial vision? Nevertheless, what a role for a talented young actress!

Moritz Bleibtreu was awarded the Silver Bear for Best Actor in Oskar Roehler's The Elementary Particles. Adapted from French writer Michel Houellebecq's outrageous novel about elementary sex as explored by fumbling, introverted half-brothers, Moritz Bleibtreu's Bruno is an incurably eros-obsessed teacher, while Christian Ulmen's straight-laced Michael works at an "artificial procreation research institute." As good as Bleibtreu is as the puzzled dreamer, it's Martina Gedeck as the partner willing to fulfill his sexual obsessions 
that steals the show. Jürgen Vogel - actor, co-author and co-producer of Matthias Glasner's The Free Will - was awarded the Silver Bear for Individual Artistic Contribution. He plays a rapist who has just been released from a long prison term for repeated rape offences, a role that demands constant screen presence for nearly three hours. Much can be said for the slow pace of the film, for rape shown in real time can be a ghastly and unnerving affair. However, it's the presence of Swiss actress Sabine Timoteo as the young vulnerable woman in the rapist's life that lends the film its final moment of credibility.

\title{
Asian Reflections
}

An Iranian comedy stood out above all the other Asian entries at the Berlinale. Awarded a share of the runner-up Silver Bear-Grand Jury Prize, Jafar Panahi's Offside prompted howls of laughter from a delighted audience. The scene is a soccer game at an overcrowded Azadi Stadium in Tehran, where Iran is battling Bahrain in a key match to qualify for the World Cup this summer in Germany. Here, six plucky Iranian girls, mostly rabid soccer fans, are using their wits and helpful disguises to enter the stadium as boys with caps, garb, pennants, and painted faces. One even dons a soldier's uniform, an indiscretion that could easily lead to family disgrace and a jail sentence. The girls never get to see the game - instead, they are placed "offside" in a pen under the guard of a friendly soldier who wants to watch the game as badly as they do. The rest is an ongoing dialogue between the girls and the guards about the whys and wherefores for forbidding women to enter a soccer stadium in the first place. To Jafar Panahi's credit, each of the non-actors (one of the guards, I was told, speaks a jumbled Farsi with a heavy Azeri accent) is a windfall to this amusing tale on nonsequiturs as it unfolds. For, as Jafar Panahi has so aptly demonstrated in past films, particularly in The White Balloon (1995), illogical answers to logical questions can bring tears of laughter.

\section{References}

\section{AWARDS}

\section{INTERNATIONAL JURY}

\section{Golden Bear}

Grbavica (Bosnia-Herzegovina-Croatia-Austria-Germany)

dir Jasmila Zbani

Silver Bear, Grand Jury Prize - ex aequo

En Soap (A Soap, Denmark-Sweden)

dir Pernille Fischer Christensen

Offside (Iran), dir Jafar Panahi

Silver Bear, Best Director

Michael Winterbottom, Mat Whitecross, The Road to Guantanamo (UK)

Silver Bear, Best Actress

Sandra Hüller, Requiem (Germany), dir Hans-Christian Schmid

Silver Bear, Best Actor

Moritz Bleibtreu, Elementarteilchen (The Elementary Particles, Germany)

dir Oskar Roehler

Silver Bear, Individual Artistic Contribution

Jürgen Vogel, as actor, co-author and co-producer, Der freie Wille (The Free Will, Germany)

dir Matthias Glasner

Silver Bear, Best Film Music

Peter Kamm, Isabella (Hongkong-China)

dir Pang Ho-Cheung

\author{
Alfred Bauer Prize \\ El custodio (The Shadow, Argentina-Germany) \\ dir Rodrigo Morena
}


First Feature Award Jury

Best First Feature Award

En Soap (A Soap, Denmark-Sweden)

dir Pernille Fischer Christensen

International Short Film Jury

Competition

Golden Bear, Short Film

Aldrig som första gången (Never Like the First Time, Sweden)

dir Jonas Odell

Silver Bear, Short Film - ex aequo

Gratte-papier (Penpusher, France)

dir Guillaume Martinez

Our Man in Nirvana (Germany)

dir Jan Koester

Special Mention

El día que morí (The Day I Died, Argentina-USA)

dir Maryam Keshavarz

Panorama

Panorama Short Film Award

Tes cheveau noirs Ihsan (Your Dark Hair Ihsan, USA)

dir Tala Hadid

Special Mention

Love This Time (Australia)

dir Rhys Graham

Prix UIP Berlin

El cerco (The Fence, Spain)

dir Ricardo Iscar, Nacho Martin

DAAD Short Film Award

Barburot (Swanettes, Israel)

dir Rony Sasson

Children's Film Festival-14 plus

Children's Jury

Crystal Bear, Best Feature Film

Drømmen (We Shall Overcome, Denmark-UK)

dir Niels Arden Oplev

\section{Special Mention}

Ang pagdadalaga ni Maximo Oliveros (The Blossoming of Maximo Oliveros, Philippines)

dir Auraeus Solito

Crystal Bear, Best Short Film

Aldrig en absolution (Never an Absolution, Sweden)

dir Cameron B. Alyasin

Special Mention

O kleftis (The Thief, Greece)

dir Irina Boiko 


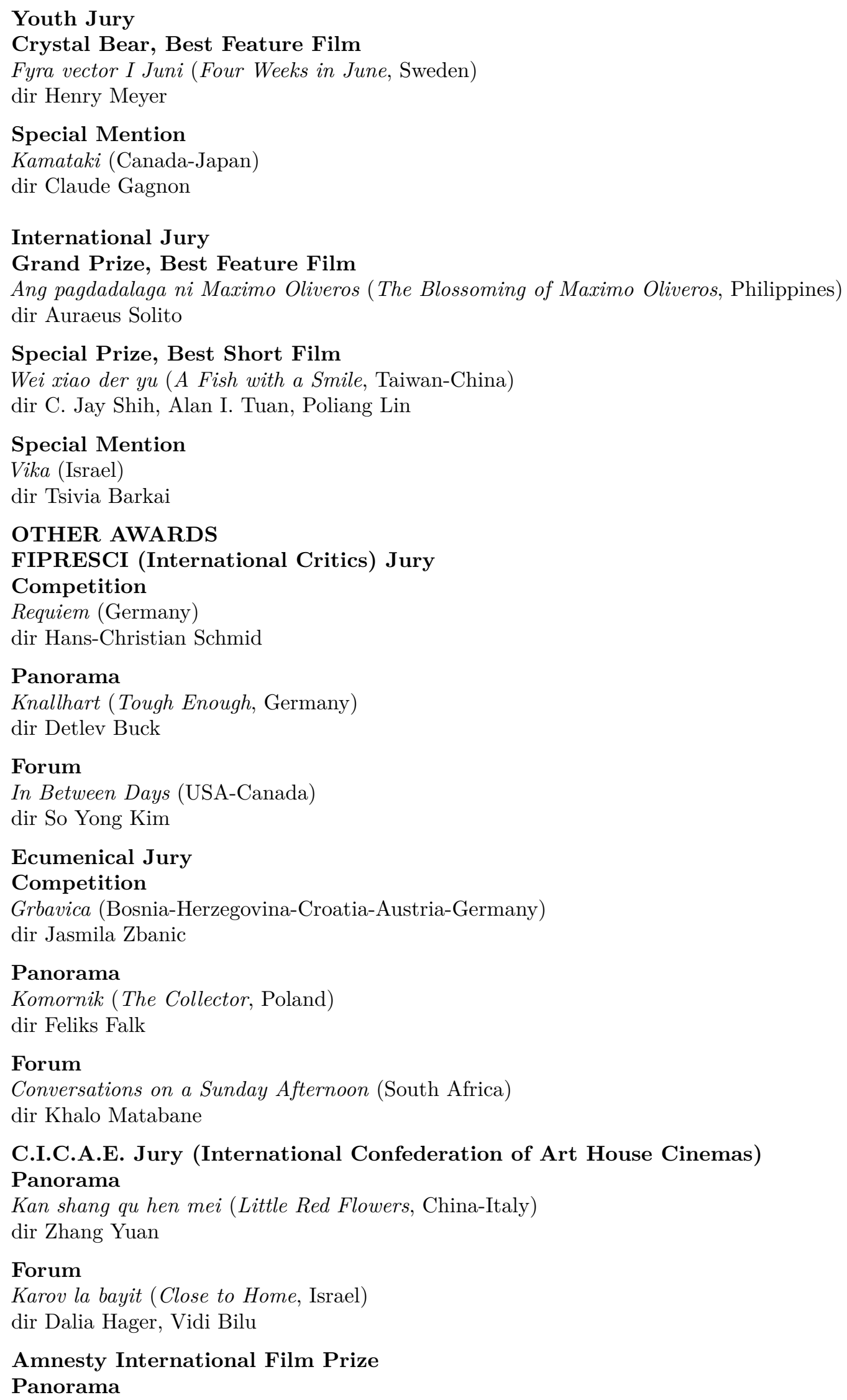

Forum

Karov la bayit (Close to Home, Israel) dir Dalia Hager, Vidi Bilu

Amnesty International Film Prize Panorama 
$\ddot{U}$ nergiz biskivin (Narcissus Blossom, Iraq-France)

dir Masoud Arif Salih, Hussein Hassan Ali (Panorama)

Prize of Guild of German Art House Cinemas

Competition

Die freie Wille (The Free Will, Germany)

dir Matthias Glasner

\author{
Label Europa Cinemas \\ Panorama \\ Knallhart (Tough Enough, Germany) \\ dir Detlev Buck \\ Peace Film Award \\ Competition \\ Grbavica (Bosnia-Herzegovina-Croatia-Austria-Germany) \\ dir Jasmila Zbanic
}

Wolfgang Staudte Prize

Forum

Babooska (Austria-Italy)

dir Tizza Covi, Rainer Frimmel

NETPAC (Network for Promotion of Asian Cinema) Prize

Forum

Dear Pyongyang (Japan)

dir Yang Yong-hi

\title{
Caligari Prize
}

\section{Forum}

37 Uses for a Dead Sheep (UK-Turkey)

dir Ben Hopkins

Dialogue and Perspective Award

Perspektive Deutsches Kino

Der Lebensversicherung (Running on Empty)

dir Bülent Akinci

\section{Femina Film Prize}

Yasmin Khalifa and Carola Gauster, for Set Design in Bye Bye Berlusconi! (Germany)

dir Jan Henrik Stahlberg

Teddy Awards

Feature Film - Children's Film Festival-14 plus

Ang pagdadalaga ni Maximo Oliveros (The Blossoming of Maximo Oliveros, Philippines)

dir Auraeus Solito

Documentary - Forum

Au-delà de la haine (Beyond Hatred, France)

Olivier Meyrou

Short Film - Competition

El Diá que morí (The Day I Died, Argentina-USA)

dir Maryam Keshavarz 
Teddy Jury Award - Forum

Combat (Belgium), Patrick Carpentier

Manfred Salzgeber Prize - Panorama

Bubot niyar (Paper Dolls, Israel-Switzerland)

dir Tomer Heymann

Siegessäule Readers Award - Panorama

Bubot niyar (Paper Dolls, Israel-Switzerland)

dir Tomer Heymann

Panorama Audience Award

Feature Film

Bubot niyar (Paper Dolls, Israel-Switzerland)

dir Tomer Heymann

\section{Short Film}

Hayelet bodeda (The Substitute, Israel)

dir Talya Lavie

Berliner Morgenpost Readers' Prize

A Prairie Home Companion (USA)

dir Robert Altman

Berlinale Talent Campus Awards

Volkswagen Score Competition

Alasdair Reid (UK)

Talent Movie of the Week

High Maintenance (USA)

dir Philip Van

\section{Author Information}

Ron HOLLOWAY (1933-2009) was an American critic, film historian, filmmaker and correspondent who adopted Europe as his home in the early fifties and spent much of his life in Berlin. He was an expert on the study of German cinema and against all odds produced, with his wife Dorothea, the journal German Film, keeping us up-to-date with the work of directors, producers and writers and the showing of German films around the world.

In 2007, Ron Holloway and his wife were awarded the Berlinale Camera Award. Ron also received the Bundesverdienstkreuz (German Cross of Merit), Polish Rings, Cannes Gold Medaille, the American Cinema Foundation Award, the Diploma for Support of Russian Cinema and an honorary award from the German Film Critics' Association.

Ron was also a valued contributor to Kinema for the past fifteen years. 